\title{
Knowledge Management Technology Using Ontologies, Cognitive Models and Production Expert Systems
}

\author{
Liudmila Massel \\ Melentiev Energy Systems Institute \\ of Siberian Branch of the Russian \\ Academy of Sciences \\ Irkutsk, Russia \\ massel@isem.irk.ru
}

\author{
Aleksei Massel \\ Melentiev Energy Systems Institute \\ of Siberian Branch of the Russian \\ Academy of Sciences \\ Irkutsk, Russia \\ amassel@gmail.com
}

\author{
Dmitrii Pesterev \\ Melentiev Energy Systems Institute \\ of Siberian Branch of the Russian \\ Academy of Sciences \\ Irkutsk, Russia \\ pesterev.dmitriy@gmail.com
}

\begin{abstract}
The article proposes a knowledge management technology based on the joint use of ontologies, cognitive models and production expert systems. Methods and tools of semantic modeling (primarily ontological and cognitive), developed in the team of authors, were applied within the framework of a two-level research technology of energy security research. An important components of knowledge management technology are the methods of cognitive modeling and the transformation of cognitive models into production rules of the expert system. The proposed approach provides automation of the analysis and interpretation of cognitive maps using production expert systems, which, in turn, allows to reduce the human factor influence and improve the quality of preparation and substantiation of recommendations for decision making. The stages of the proposed knowledge management technology, the algorithm for transforming the cognitive model, the modification and development of tools to support the proposed technology based on the agent approach are considered. Examples of ontologies, cognitive maps and the results of cognitive maps converting into production rules of an expert system are given. The technology has been tested in studies of energy security problems, but may have wider application.
\end{abstract}

Keywords-knowledge management, ontology, cognitive models, expert system, energy security.

\section{INTRODUCTION}

The article considers the problem of knowledge management in scientific research and the proposed approach to solution this problem, which based on the integration of ontological, cognitive models and production expert systems. The relevance of the problem is due to the increasing value of expert knowledge and the need to develop new approaches, methods and tools for intelligent decision support based on the use of modern intelligent information technologies, including semantic modeling technologies.

The approbation was carried out on the example of studies of the energy security problem, but the proposed approach to knowledge management can be more widely applied. The core of the proposed technology is the technique of cognitive modeling and the transformation of cognitive models into the production rules of the expert system, as well as tools to support the proposed technology, based on the agent approach. In studies of the energy security problem cognitive modeling technology has earned recognition, but the analysis and interpretation of cognitive maps has until recently been carried out manually by an expert. The transition from cognitive models to production expert systems allows us to automate this stage and reduce the number of possible errors. The two-level technology for researching of the energy security problem, the place in it of cognitive and ontological modeling, and the knowledge management technology proposed by the authors are described below.

\section{TWO-LEVEL TECHNOLOGY FOR ENERGY SECURITY RESEARCH}

Traditionally, at the Institute of Energy Systems named after L.A. Melentyev SB RAS to study of the energy security (ES) problems used economic and mathematical models of the fuel and energy complex (FEC), software systems for their implemention and a computational experiment [1]. In modern conditions, researchers, as a rule, have the problem of obtaining sufficient and reliable initial information, which makes it difficult or inappropriate to use detailed mathematical models. In addition, the multivariate computational experiment and the combinatorial approach adopted in ES research leads to the need to analyze a large number of options (up to 5 million), which significantly increases the load on the expert.

The authors proposed to apply a two-level research technology based on the concepts of semantic modeling and knowledge management [2]. Semantic modeling includes ontological [3-4], cognitive, event, and probabilistic modeling (modeling techniques and supporting tools developed by the author's team) [5]. In this case, both explicit (published and presented in electronic form) and implicit (Brain ) knowledge are used [6]. Two-level technology assumes that at the 
first level, the expert performs a qualitative analysis of the problem using the tools of semantic modeling and selects the most likely (expedient) options for the development of energy sector (not 5 million, but, for example, 5 options). At the second level, justification of these options can be performed (computational experiment using traditional software systems and economic-mathematical models). Fig. 1 illustrates the architecture of an intelligent tool environment supporting this technology.

An important place in the proposed technology is occupied by cognitive modeling and the supporting tool CogMap, which are discribed in more detail below.

\section{THE TRANSITION FROM COGNITIVE MODELS TO THE PRODUCTION RULES OF THE EXPERT SYSTEM}

Cognitive modeling is the construction of cognitive models represented by oriented graphs, in which the vertices correspond to factors (concepts), and arcs correspond to the connections between factors, positive or negative, depending on the nature of the cause-effect relationship. Arcs are characterized by weighting coefficients, in the simplest case " +1 " or "-1", in more complex cases, these coefficients are calculated or described by analytical functions [7]. The graphic representation of cognitive models is called cognitive maps. Recently, cognitive modeling is becoming increasingly widespread, both in Russia [8, 9] and in other countries [10, 11].
In the study of ES problems, cognitive modeling is used for situational analysis of the ES problem and modeling of ES threats, which are understood as adverse events for the energy sector. In Figure 2 shows an example of a cognitive map built with help of the CogMap tool.

The basis for the development of cognitive models in our case are ontological models [12]. An example of a typical ontology that structures the basic concepts used in cognitive models is shown in Fig. 3 [13]. At the same time, to construct the ontological space of knowledge, the authors use a fractal stratified approach to structuring knowledge [14].

Until recently, the analysis and interpretation of cognitive maps was carried out by an expert manually, which could lead to errors and incorrect conclusions. Considering the reflection in the cognitive maps of cause-and-effect relationships, which are well displayed by the production rules "If the premise then the consequence", it was proposed to automate the analysis of cognitive maps using production expert systems. The rules describing a specific cognitive model can be organized as a fragment of the knowledge base of a production expert system. Thus, a preliminary analysis of the cognitive model and conclusions on a set of rules can be carried out by an expert system, and an expert or Decision Maker can verify the accuracy and / or adjust these conclusions.

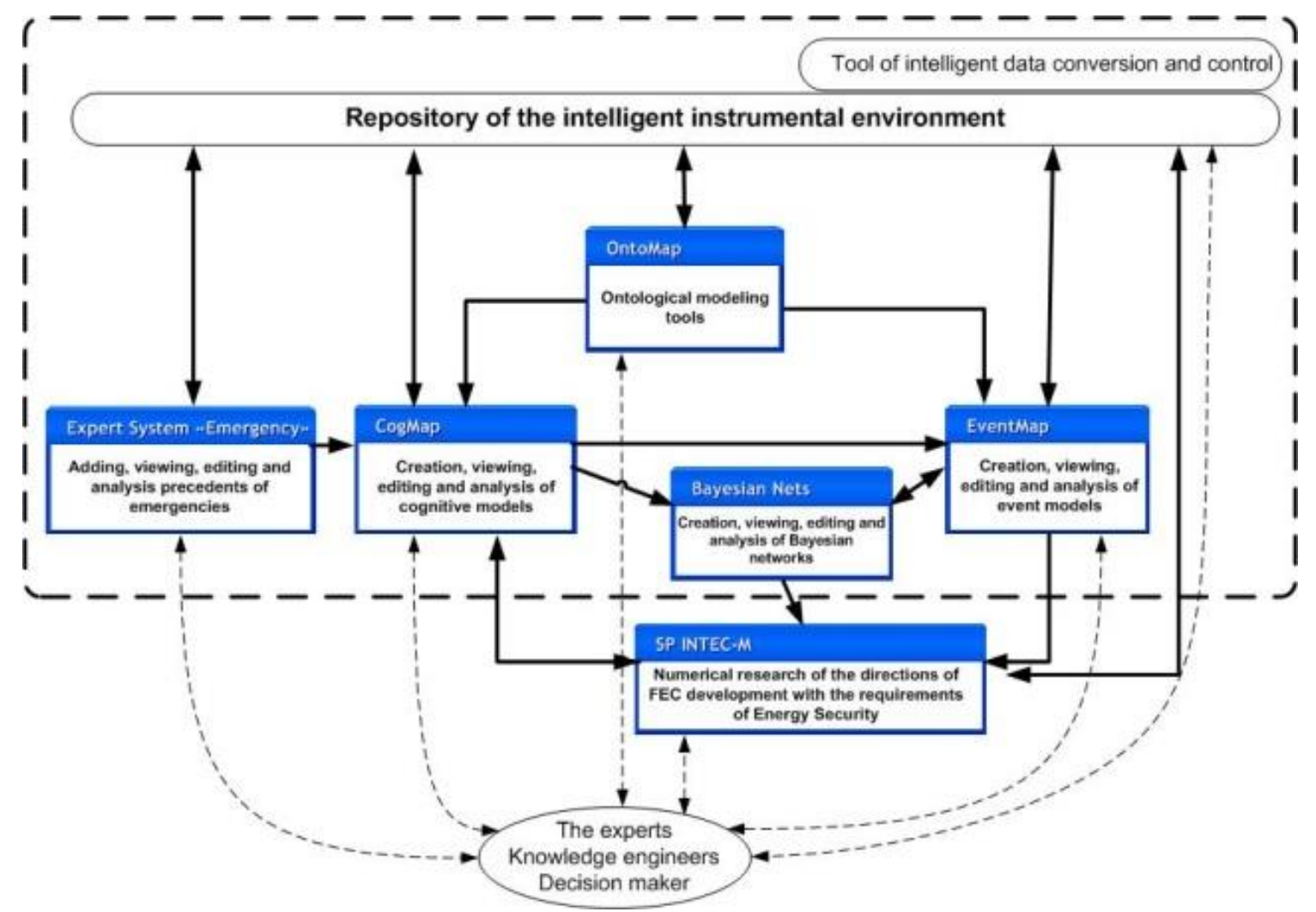

Fig.1.The architecture of Intelligent IT-environment to support two-level research technology 


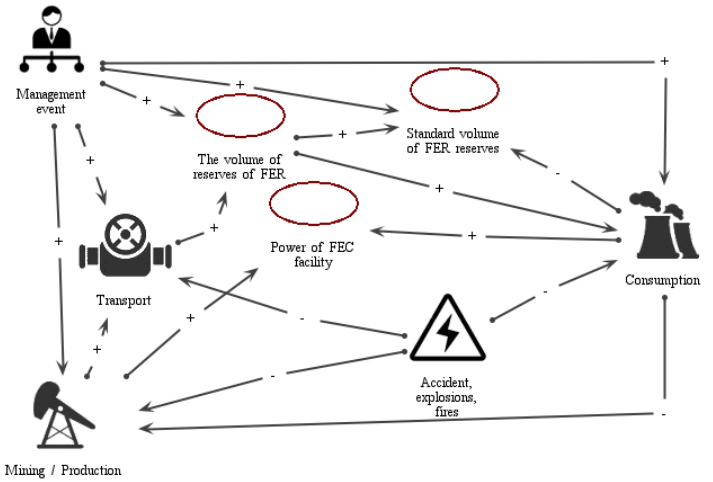

Fig.2.Fragment of the cognitive map for the threat "Accidents, explosions, fires (AEF)" in CogMap notation

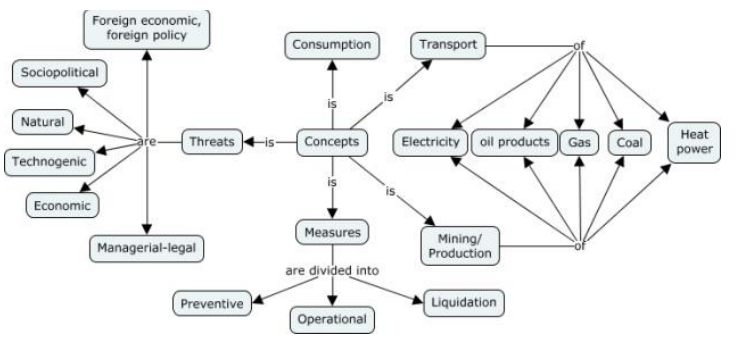

Fig.3.Basic ontology for cognitive modeling

\section{KNOWLEDGE MANAGEMENT TECHNOLOGY USING ONTOLOGICAL, COGNITIVE MODELS AND THE PRODUCTION EXPERT SYSTEM}

Consideration of the full cycle of extracting, presenting and interpreting knowledge allows us to speak not just about the technology of transition from cognitive maps to production rules, but about knowledge management technology [15], including the stages of knowledge extraction, knowledge presentation, knowledge representations transforming (moving from one type of representation to another) and interpretation of knowledge. The knowledge management technology is presented in table 1 and illustrated in Fig. 4.
TABLE I. KNOWLEDGE MANAGEMENT TECHNOLOGY USING ONTOLOGIES, COGNITIVE MODELS AND PRODUCTION EXPERT SYSTEM

\begin{tabular}{|c|c|c|c|}
\hline $\begin{array}{c}\text { Stage } \\
\text { № }\end{array}$ & Stage content & $\begin{array}{c}\text { Tools } \\
\text { (performers) }\end{array}$ & Stage result \\
\hline 1 & $\begin{array}{l}\text { Domain analysis } \\
\text { and knowledge } \\
\text { extraction }\end{array}$ & $\begin{array}{l}\text { Expert, } \\
\text { researcher } \\
\text { (cognitive } \\
\text { engineer) }\end{array}$ & $\begin{array}{l}\text { Basic domain } \\
\text { concepts and } \\
\text { relationships } \\
\text { between them }\end{array}$ \\
\hline 2 & $\begin{array}{l}\text { Construction of } \\
\text { ontologies }\end{array}$ & $\begin{array}{l}\text { OntoMap, } \\
\text { CMapTools, } \\
\text { Protégé }\end{array}$ & $\begin{array}{l}\text { Knowledge } \\
\text { represented as } \\
\text { ontology }\end{array}$ \\
\hline 3 & $\begin{array}{l}\text { Construction of } \\
\text { ontology-based } \\
\text { cognitive maps }\end{array}$ & CogMap & $\begin{array}{l}\text { Knowledge } \\
\text { represented as } \\
\text { cognitive map }\end{array}$ \\
\hline 4 & $\begin{array}{l}\text { Construction of } \\
\text { an incidence } \\
\text { matrix for a } \\
\text { cognitive map } \\
(\mathrm{CM})\end{array}$ & $\begin{array}{l}\text { CM } \\
\text { conversion } \\
\text { agent }\end{array}$ & $\begin{array}{l}\text { Knowledge } \\
\text { presented as } \\
\text { incidence matrix } \\
\text { for } \mathrm{CM}\end{array}$ \\
\hline 5 &  & $\begin{array}{l}\mathrm{CM} \\
\text { conversion } \\
\text { agent }\end{array}$ & $\begin{array}{l}\text { Knowledge } \\
\text { presented as } \\
\text { production rules }\end{array}$ \\
\hline 6 & $\begin{array}{l}\text { CM analysis } \\
\text { (logical inference } \\
\text { in ExS) }\end{array}$ & $\begin{array}{l}\text { Expert } \\
\text { System }\end{array}$ & $\begin{array}{l}\text { Output of results } \\
\text { (interpretation of } \\
\text { knowledge in the } \\
\text { form of CM) }\end{array}$ \\
\hline 7 & $\begin{array}{l}\text { Analysis of } \\
\text { output results }\end{array}$ & Expert & $\begin{array}{l}\text { Recommend a } \\
\text { solution or refine } \\
\text { knowledge (go to } \\
\text { stage 2,3) }\end{array}$ \\
\hline
\end{tabular}

As part of the proposed technology, ontological engineering of the domain is carried out at the initial stages and ontologies are built using the following tools: authorial OntoMap or common CMapTools, Protégé, etc. At stages $4-5$, the CM is converted into the production rules of the expert system, which carries out the CM analysis (logical inference) at the 6th stage. At the final stage, the expert considers the results of the inference and recommends a solution or refines the initial premises (by editing ontological or cognitive models).

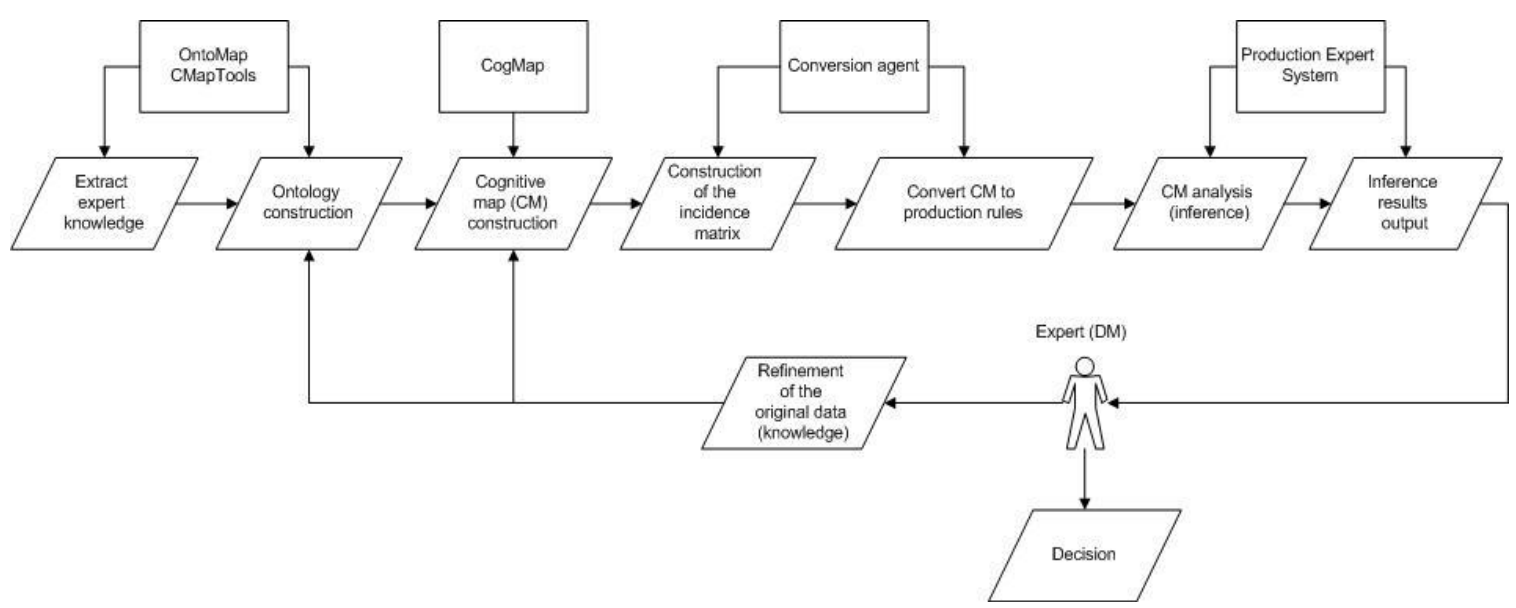

Fig.4.Knowledge management technology using ontologies, cognitive models and production expert system 


\section{SUPPORT TOOLS OF PROPOSED TECHNOLOGY}

To support the proposed technology, a modification of the cognitive modeling technique and the CogMap tool were performed and the CM conversion agent was developed.

The developed module for saving the cognitive map in the format necessary for the 4th stage, where the cognitive map in XML format is transmitted to the input of the CM conversion agent, was integrated into the CogMap tool (Table 1).

The conversion agent, in accordance with the author's algorithm, traverses the graph, forms a list of concepts (entities) and the relationships between them; further, passing through this list, forms a set of production rules in the format used by the Clips shell. When implementing the agent, four classes of objects were designed: map, entity, connection, rule.

The algorithm includes the following steps:

1. The choice of the concept in the transformed cognitive model.

2. The choice of the connection for this concept in the transformed cognitive model.

3 . If the connection is outgoing, then write in the incidence matrix at the intersection of the concept line and the relation column " 1 ", if the incoming one is "1 ", otherwise " 0 ".

4. The selection of the next relation for this concept and repeat step 3 until iterates through all the relations.

5. The selection of the next concept and repeating steps 2-4 until iterating through all the concepts; if all concepts are passed, then the "end" of this block (formation of the incidence matrix).

6. To select the cell of the first (next) row of the incidence matrix.

7. If it has " 1 ", then mark the concept associated with this cell as "premise", if "- 1 ", then mark as "consequence".

8. Go to the next row of the incidence matrix (to step 6); if the line is last, go to step 9 .

9. Make a rule according to the pattern: if "premise" then "consequence".

10. Go to the next column and repeat steps 6-9; repeat to the last column of the matrix. If the column is the last, then the "end" of the algorithm.

In fact, this algorithm can be divided into two parts. When the first part is performed (steps 1-5), a graph is traversed that represents the cognitive model, and the incidence matrix of the graph is formed. When performing the second part (steps 6-10), this matrix is analyzed in columns and a set of production rules is formed.

The resulting set of rules is transferred to the shell of the production expert system Clips. Using the Clips inference engine, the expert receives conclusions about the degree of interaction of the concepts of the cognitive map on each other, or, if the initial task required, the degree of influence of the concepts on any target concept (for example, the "Standart volume of FER reserves" in the cognitive map in Fig. 2).

\section{AN EXAMPLE OF THE PRODUCTION RULES FORMATION FOR A COGNITIVE MAP USING LINGUISTIC DESCRIPTIONS}

In Figure 5 presents a cognitive map of the threat "Reduced gas production opportunities". If the sign $\mathrm{Ci}$ is associated with each concept, linguistic descriptions of the rules can be made. They are shown below. The following is a list of the rules for the cognitive map shown in Figure 5, using linguistic descriptions of the rules:

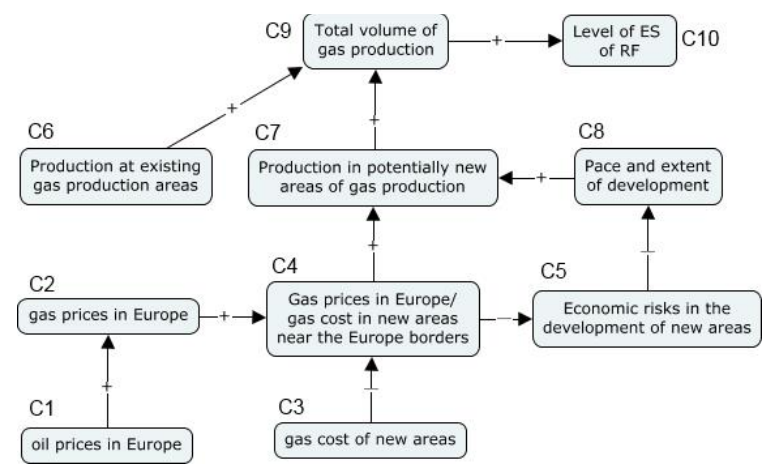

FIg.5. Cognitive map of the threat "Reduced gas production opportunities"

1. If the price of oil in Europe rises, then the price of gas in Europe rises.

Linguistic description: If $\mathrm{C} 1 \uparrow$, then $\mathrm{C} 2 \uparrow$

2. If gas prices in Europe rise, then the ratio "Gas Price / Gas Cost of New Areas at the Borders of Europe" increases.

\section{Linguistic description: If $\mathrm{C} 2 \uparrow$, then $\mathrm{C} 4 \uparrow$}

3. If the prime cost of gas in new areas is growing, then the ratio "Gas price / cost of gas in new areas near the borders of Europe" decreases.

Linguistic description: If $\mathrm{C} 3 \uparrow$ then $\mathrm{C} 4 \downarrow$

4. If the ratio "Gas price / prime cost of gas of new regions near the borders of Europe" increases, then the risks of new regions developing are reduced.

\section{Linguistic description: If $\mathrm{C} 4 \uparrow$ then $\mathrm{C} 5 \downarrow$}

5. If the risks in the development of new areas are growing, then the pace and scale of their development are falling.

\section{Linguistic description: If $\mathrm{C} 5 \uparrow$ then $\mathrm{C} 8 \downarrow$}

6 . If the ratio "Gas price / prime cost of gas of new regions near the borders of Europe" is growing, then production in potentially new regions is growing.

Linguistic description: If $\mathrm{C} 4 \uparrow$ then $\mathrm{C} 7 \uparrow$. 
7. If the pace and scale of their development is growing, then production in potentially new areas is declining.

\section{Linguistic description: If $\mathrm{C} 8 \uparrow$ then $\mathrm{C} 7 \downarrow$.}

8. If production in potentially new areas is growing, then the total volume of gas production is growing.

Linguistic description: If $\mathrm{C} 7 \uparrow$ then $\mathrm{C} 9 \uparrow$.

9. If production in existing areas is growing, then the total volume of gas production is growing.

Linguistic description: If $\mathrm{C} 6 \uparrow$ then $\mathrm{C} 9 \uparrow$.

10. If the total volume of gas production is growing, then the level of ES of the Russian Federation is growing.

Linguistic description: If $\mathrm{C} 9 \uparrow$ then $\mathrm{C} 10 \uparrow$.

Construction a translator to convert these linguistic descriptions into a representation of an expert system can be another option for implementing the proposed approach.

\section{CONCLUSION}

The article presents the knowledge management technology in scientific research, based on the use of ontologies, cognitive models and production expert system. The proposed technology includes the stages of knowledge extraction, knowledge representation, transformation of knowledge representations (transition from one type of representation to another) and interpretation of knowledge.

At present, when the importance of expert knowledge is increasing, as well as the role of intelligent tools, the proposed technology is aimed at the intelligent support of the substantiation and formation of recommendations by experts for the preparation of scientifically based and balanced decisions for Decision Makers.

The novelty of the proposed approach consists, firstly, in the integration of various intelligent technologies (ontological, cognitive modeling, expert systems) within the framework of a common technology for knowledge management in scientific research; secondly, in the automation of analysis and interpretation of cognitive maps using production expert systems. As a result, we can talk about improving the quality of preparation and substantiation of recommendations for making decisions (in our case, decisions on ensuring energy security).decisions on ensuring energy security).

\section{ACKNOWLEDGMENT}

This work was carried out as part of the scientific project of the basic research program of the SB RAS III.17.2, reg. No. AAAA-A17-117030310444-2, as well as with partial financial support from RFBR grants No. 19-07-00351, 19-57-04003, 18-07-00714, 17-07-01341.

\section{REFERENCES}

[1] Energy security of Russia: problems and solutions / Novosibirsk: SB RAS, 2011. - 198 c. ISBN 978-5-76921163-8. [Energeticheskaya bezopasnost' Rossii: problemy i puti resheniya / Novosibirsk: SO RAN, 2011. - 198 p. ISBN 978-5-7692-1163-8.] (In Russian)

[2] Massel L.V, Massel' A.G. Intelligent computing in studies of energy development trends // Bulletin of the Tomsk Polytechnic University, - 2012. T. 321. № 5. - Pp. 135-141. [Intellektual'nye vychisleniya $\mathrm{v}$ issledovaniyah napravlenij razvitiya energetiki // Izvestiya Tomskogo politekhnicheskogo universiteta, - 2012. T. 321. № 5. - S. 135-141.] (In Russian)

[3] Gavrilova T. A., Kudryavcev D. V., Muromcev D. I. Knowledge Engineering. Models and Methods: Textbook. St. Petersburg.: Publishing house «Lan'», 2016. - 324 p. [Inzheneriya znanij. Modeli i metody: Uchebnik. - SPb.: Izdatel'stvo «Lan'», 2016. - 324 s.] (In Russian)

[4] Gavrilova T.A. Ontological engineering. Knowledge Management Technologies. [Electronic resource]. http://www.kmtec.ru/publications/library/authors/ ontolog_engeneering.shtml (Date of the application: 15.09.2019) [Ontologicheskij inzhiniring. Tekhnologii menedzhmenta znanij. [Elektronnyj resurs]. - Rezhim dostupa:

http://www.kmtec.ru/publications/library/authors/ontolog_eng eneering. shtml (Data obrashcheniya: 15.09.2019)] (In Russian)

[5] Massel L.V., Massel A.G. Semantic technologies based on the integration of ontological, cognitive and event modeling // III international scientific and technical conference OSTIS-2013: Proc. Belarus, Minsk: BSUIR. -2013. - Pp. 247-250. [Semanticheskie tekhnologii na osnove integracii ontologicheskogo, kognitivnogo i sobytijnogo modelirovaniya // III mezhdunarodnaya nauchnotekhnicheskaya konferenciya OSTIS-2013: Trudy. Belarus', Minsk: BGUIR. -2013. - S. 247-250.] (In Russian)

[6] Massel L.V. Ontological engineering and knowledge management to support strategic decision making on the development of smart energy // Proccedings of XX Russian scientific conference "Enterprise Engineering and Knowledge Management (EE\&KM-2017)». M.: Plekhanov Russian University of Economics, 2017. - Pp. 59-65. ISBN 97857307-1222-5, ISBN 978-5-7307-123323-2 [Ontologicheskij inzhiniring i upravlenie znaniyami dlya podderzhki prinyatiya strategicheskih reshenij po razvitiyu intellektual'noj energetiki // Trudy XX Rossijskoj nauchnoj konferencii «Inzhiniring predpriyatij i upravlenie znaniyami (IP\&UZ - 2017)». M.: REU im. G.V. Plekhanova, 2017. - S. 59-65. ISBN 97857307-1222-5, ISBN 978-5-7307-123323-2] (In Russian)

[7] Trahtengerc E.A. Computer decision support. - M.: SINTEG, 1998. - 376 p. [Komp'yuternaya podderzhka prinyatiya reshenij. - M.: SINTEG, 1998. - 376 s.] (In Russian)

[8] Avdeeva Z.K., Kovriga S.V. Heuristic method of conceptual structuring of knowledge in the formalization of poorly structured situations based on cognitive maps / Large-Scale Systems Control. - M.: ICS RAS. 2010. - №31.- p. 6-34. [Evristicheskij metod konceptual'noj strukturizacii znanij pri formalizacii slabostrukturirovannyh situacij na osnove kognitivnyh kart / Upravlenie bol'shimi sistemami. - M.: IPU RAN. 2010. - №31.- S. 6-34.] (In Russian)

[9] Massel A.G. Cognitive modeling in studies of energy security problems: applications and development prospects. / Proceedings of International Congress on Intelligent Systems and Information Technologies «IS\&IT'14». - M.: Fizmatlit, 2014. - T.2. - Pp. 153-158 [Kognitivnoe modelirovanie v issledovaniyah problem energeticheskoj bezopasnosti: primeneniya i perspektivy razvitiya. / Trudy Kongressa po intellektual'nym sistemam i informacionnym tekhnologiyam «IS\&IT’14». - M.: Fizmatlit, 2014. - T.2. - S. 153-158] (In Russian)

[10] Groumpos P. ,Stylios C., Modelling supervisory control systems using fuzzy cognitive maps/ Chaos, Solitons \& Fractals. - 2000, Vol. 11. - № 1-3. - Pp. 329-336. 
[11] Papageorgiou E., Stylios C., Groumpos P. An integrated twolevel hierarchical system for decision making in radiation therapy based on fuzzy cognitive maps / IEEE Transactions on Biomedical Engineering. - 2003, Vol. 50. - № 12. - Pp. 1326-1339.

[12] Massel L.V., Vorozhcova T.N., Pyatkova N.I. Ontological engineering to support strategic decision making in the energy sector / Ontology of designing. - 2017. Vol. 7. №1 (23). - Pp. 66-76. - DOI: 10.18287/2223-9537-2017-7-1-66-76. [Ontologicheskij inzhiniring dlya podderzhki prinyatiya strategicheskih reshenij v energetike/ Ontologiya proektirovaniya. - 2017. Tom. 7. №1 (23). - S. 66-76. - DOI: 10.18287/2223-9537-2017-7-1-66-76.] (In Russian)

[13] Massel A.G., Pesterev D.V. Transformation of cognitive models into knowledge base of production expert system // Proceedings of the 19th International Workshop on Computer Science and Information Technologies. Germany, Baden-
Baden. - Publisher Ufa: USATU. Vol. 1, 2017. - Pp. 121124. ISBN 978-5-1030-8, ISBN 978-4-4221-1031-5.

[14] Massel L.V. Fractal approach to structuring knowledge and examples of its application / Ontology of designing. - 2016. Vol. 6, №2 (20). - Pp. 149-161. - DOI: 10.18287/2223-95372016-6-2-149-161. [Fraktal'nyj podhod k strukturirovaniyu znanij i primery ego primeneniya / Ontologiya proektirovaniya. - 2016. T. 6, №2 (20). - S. 149-161. - DOI: 10.18287/2223-9537-2016-6-2-149-161.] (In Russian)

[15] Tuzovsky A.F., Chirikov S.V., Yampolsky V.Z. Knowledge Management Systems (Methods and Technologies) / Under the General Ed. Yampolsky V.Z. - Tomsk: NTL Publishing House, 2005 - -260 p. [Sistemy upravleniya znaniyami (metody i tekhnologii) / Pod obshchej red. Yampol'skogo V.Z. - Tomsk: Izd-vo NTL, 2005. - 260 s.] (In Russian) 